* Corresponding author

Phone +421556022470

E-mail address:roberthunady@tukesk

(Róbert Huňady, Ing. Ph.D)

Article information

Article history: AMS-Volume15-No.4-00124-11

Received 4 April 2011

Accepted 15 May 2011

\section{An Application of High-speed Digital Image Correlation in Determination of Modal Parameters}

\author{
František Trebuňa, Róbert Huňady* , Zdenko Bobovský, Martin Hagara
}

Department of Applied Mechanics and Mechatronics, Faculty of Mechanical Engineering, Letná 9, 04200 Košice,

Slovak Republic

\section{BIOGRAPHICAL NOTES}

František Trebuňa, Dr.h.c. mult. prof. Ing. CSc. is a professor of applied mechanics, Head of the Department of Applied Mechanics and Mechatronics and Dean of the Faculty of Mechanical Engineering. He is author of 10 monographs, 12 university textbook, special book publications, 12 university notebooks and more than 300 publications in journals and conference proceedings at Slovakia abroad. He is author of important projects and engineering works. He received several prizes at home and abroad. He received three titles Doctor Honoris Causa (DHC) including two from foreign universities for the development of applied mechanics and mechatronics.

Róbert Huňady, Ing. Ph.D. (1981) he received M.S. degree in mechanical engineering from Technical University of Košice, Slovakia in 2007. In 2009, he attended EC Marie Curie Training Program SIMVIA2 at Czech Technical University of Prague, Czech republic. He finished his doctoral study in study field Applied mechanics in Faculty of mechanical engineering at Technical University of Košice, Slovakia in 2010. Since 2010 he has been working as lecture at Department of Applied Mechanics and Mechatronics at Technical University of Košice, Slovakia. His professional activity is oriented into the area of modern optical methods of experimental mechanics such as high-speed digital image correlation, electronic speckle pattern interferometry and laser doppler vibrometry. He is author or co-author of more than 30 journals, conference papers and works aimed particularly at experimental modal and vibration analysis.

Zdenko Bobovský, Ing. Ph.D. is an assistant of the Department of Applied Mechanics and Mechatronics at Faculty of Mechanical Engineering at Technical University of Košice. He received B.Sc. degree in production systems with industrial robots and manipulators (2002), M.Sc degree in Construction of robotics system (2005), M.Sc degree in automotive production (2007), Medal of Dean for excellent student (2007) and Ph.D in Production system at the same faculty (2009). His current fields of interest are mechatronics, metamorphous self-reconfigurable modular robotic systems and applied mechanics.

Martin Hagara, Ing. (born in 1985), after successful completion of his study at the Gymnasium of Pavol Orszagh Hviezdoslav in Kezmarok he has started studies at the Faculty of Mechanical Engineering of the Technical university of Kosice. He graduated a bachelor-degree study in Mechatronics in 2008. Thereafter he continued an engineer-degree study in Applied Mechanics. He defended his diploma thesis "Application of digital image correlation in solving problems of modal analysis" in 2010. Because of the results he has reached, he has been awarded the medal of excellent student by dean of the Faculty of mechanical engineering of the Technical university of Kosice. Nowadays he is a student of PhD-degree study in Applied mechanics, where he car- 
ries out research in methodics of digital image correlation in solving problems of mechanical structures dynamics.

\section{KEYWORDS}

Digital Image Correalation, Experimental Modal Analysis, Modan

\section{ABSTRACT}

The paper deals with digital image correlation method that belongs to the most modern optical method used in experimental mechanics. The main attention is devoted to an application of this method in determination of modal parameters. There is described a methodology of measurement of eigenshapes and eigenfrequencies by high-speed correlation system Q-450 Dantec Dynamics. A part of this procedure is software called Modan that was designed and created as effective tools for evaluation of such type of experimental measurements.

\section{Introduction}

Every structure has a tendency to vibrate under certain frequencies. This phenomenon is known as a resonance. In resonance state the amplitudes can reach critical values. From this point of view, vibrations created in majority of mechanical systems are undesirable not only because of increased noise and dynamical stresses that can in some cases lead to malfunction or failure of structure, but also due to loss of energy and decreasing of efficiency. There are known many cases where the excessive vibrations of one or several parts of structure led to their damage or decreasing of lifetime. That is the reason why the dynamic analysis of structure is a part of its design stage. After its realization and during introduction of the structure into operation is necessary to verify assumptions of analytical solution [10] by experiments.

Experimental determination of modal parameters from measured data is known as a modal testing or experimental modal analysis. Its cornerstone lies on investigation of relation between excitation and response of the object in frequency domain. For the measurement in the experimental modal analysis are mostly used the sensors of acceleration [1]. Due to progress that has been achieved in the area of computer techniques there are more in forefront also modern optical systems that allow to provide highspeed contactless and full-filed measurements of space displacements or velocities of object. To this category of measurement systems belong laser vibroscanners or devices working on the principle of pulse ESPI or digital image correlation, which will be described into details below.

\section{Digital image correlation (DIC)}

In the 3D digital image correlation technique, stochastic speckle patterns on specimen surfaces are observed by two cameras in a stereoscopic setup (Fig. 1). The digitized images are compared to match subsets - so called facets (Fig. 2) - from one image to another by using an image correlation algorithm.

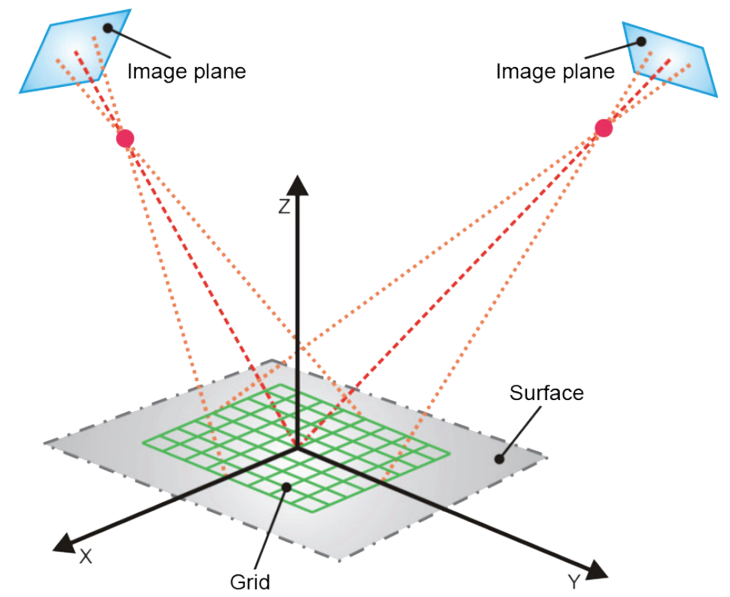

Fig. 1: The principle of spatial image correlation.

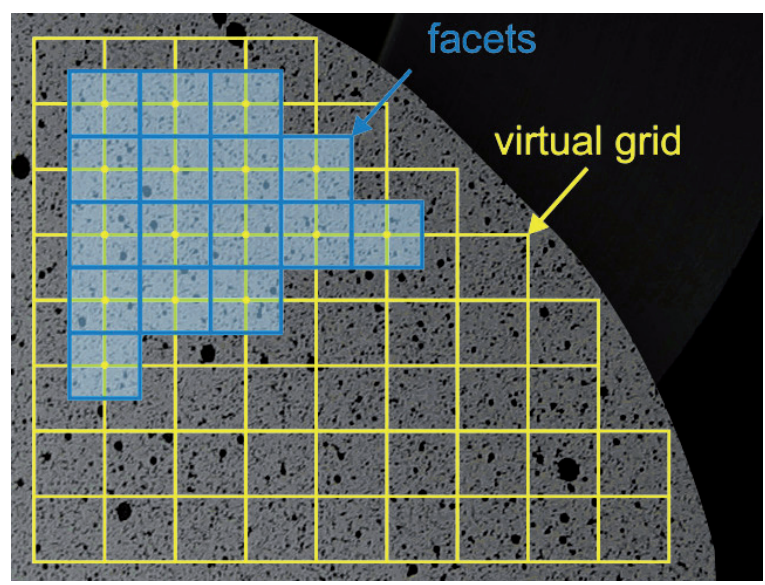

Fig. 2: Virtual grid and facets determined on stochastic speckle pattern of the object surface.

With knowledge of the imaging parameters for each camera and the orientations of the cameras with respect to each other, the position of each object point in three dimensions is calculated. In order to evaluate surface displacements and strains on the object 
surface, a series of measurements is taken, while the specimen surface is moved due to a loading. The correlation algorithm tracks the observed gray value patterns for each camera and transforms corresponding facet positions in both cameras into $3 \mathrm{D}$ coordinates for each step, resulting in a track of each surface facet in 3D space. As the surface deformation is measured pointwise, displacements of individual surface points and subsequently surface strains can be evaluated [2].

\section{Using the DIC method in modal analysis}

In the modal analysis can be applied the correlation systems that provide high-speed dynamic measurements with scanning frequency at least $500 \mathrm{fps}$. The program environments of these measurement systems do not have analytical instruments needed for evaluation of such experiment. For example in the case of broadband excitation, the system is not able to represent the shapes of corresponding eigenfrequencies. In order to determinate them, it is necessary to accomplish additional numerical processing of results in different environment. At the Department of Applied Mechanics and Mechatronics, Faculty of Mechanical Engineering, TU in Košice was developed software Modan [3][4][6] that allows such visualization for system Q-450 Dantec Dynamics [1][2][9]. The principle of program lies on frequency analysis of timedependent charts of displacements of all points of a grid of correlated object's surface that was excited by broadband frequency by one of the following method:

\section{- impact hammer, \\ - electromagnetic exciter with stochastic signal, \\ - acoustically by white noise.}

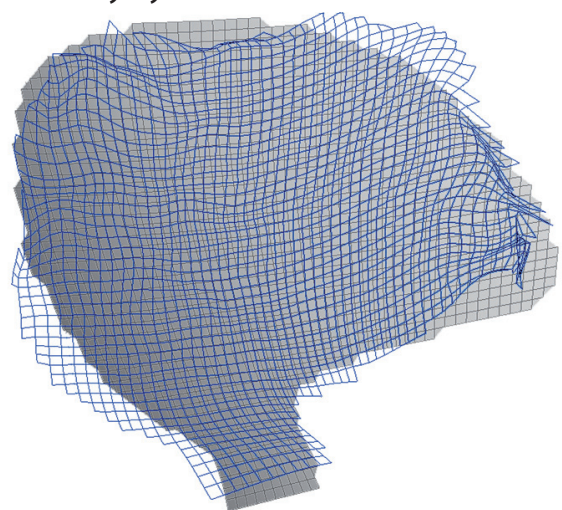

Fig. 3: The grid of resulting deformation of surface of excited object (magnification 1000x).
Under such type of excitation are excited all modes in given frequency range at once [5]. Correlation system records time-dependent deformation of surface on object that consists of partial deformations of individual modes. In Fig. 3 is example of deformation of a grid of ventilator blade excited by modal hammer. The time-dependent space displacements measured by the system Q-450 are then transformed in program Modan by Fast Fourier Transformation (FFT). Accordingly, the eigenshapes of individual eigenfrequencies are separated.

\section{Modan v.1.0 is able to represent:}

- average frequency spectrum of displacements of surface points on object ( $x, y, z$ or resulting) in linear or logarithmic coordinates,

- eigenshapes of vibration (resulting or their components) that correspond to eigenfrequencies of object.

Conception of the program allows its full using not only in modal analysis, but also in analysis of vibration. The results are available promptly and beside of visualization they can be exported in the form of graphical and data files [6].

\section{A basic principle of the modan algorithm}

System Q-450 stores the results of measurement into files HDF5 [7][8], every one from which belongs to one time step of measurement. The files have hierarchic structure that consists of three main groups - coordinates, displacements, and strains, respectively. Every group consists of several data sets with values measured in nodes of contour grid. Exported files with results represent data inputs into program Modan. Algorithm of program can be divided into two parts. Te output of the first part is average frequency spectrum of displacements of all points of contour grid. In ideal case the peaks of graph identify the eigenfrequencies of object. The user then chooses eigenfrequencies the eigenshapes of which it will plot. Graphical representation of eigenshape is the task of second part of algorithm.

The description of algorithm will be restrained only to processing of displacement in direction of axis $z$. The displacements in direction $x$ and $y$ are processed similarly and so they are not considered in explanation [6].

The algorithm creates from input data three-dimensional matrices on which are provided neces- 
sary mathematical operations. The input for computation consists of the following data sets:

\section{- mask of surface,}

- coordinates of nodal points of contour grid,

- displacements of nodal points $x, y, z$.

From the file named series_step_0000.hdf5, in which are saved results of correlation of the 0 -th reference step are read spatial coordinates of grid points. The algorithm creates matrix of reference coordinates CoorXYZ (Fig. 4) that will represent one of the input for the second part of algorithm.
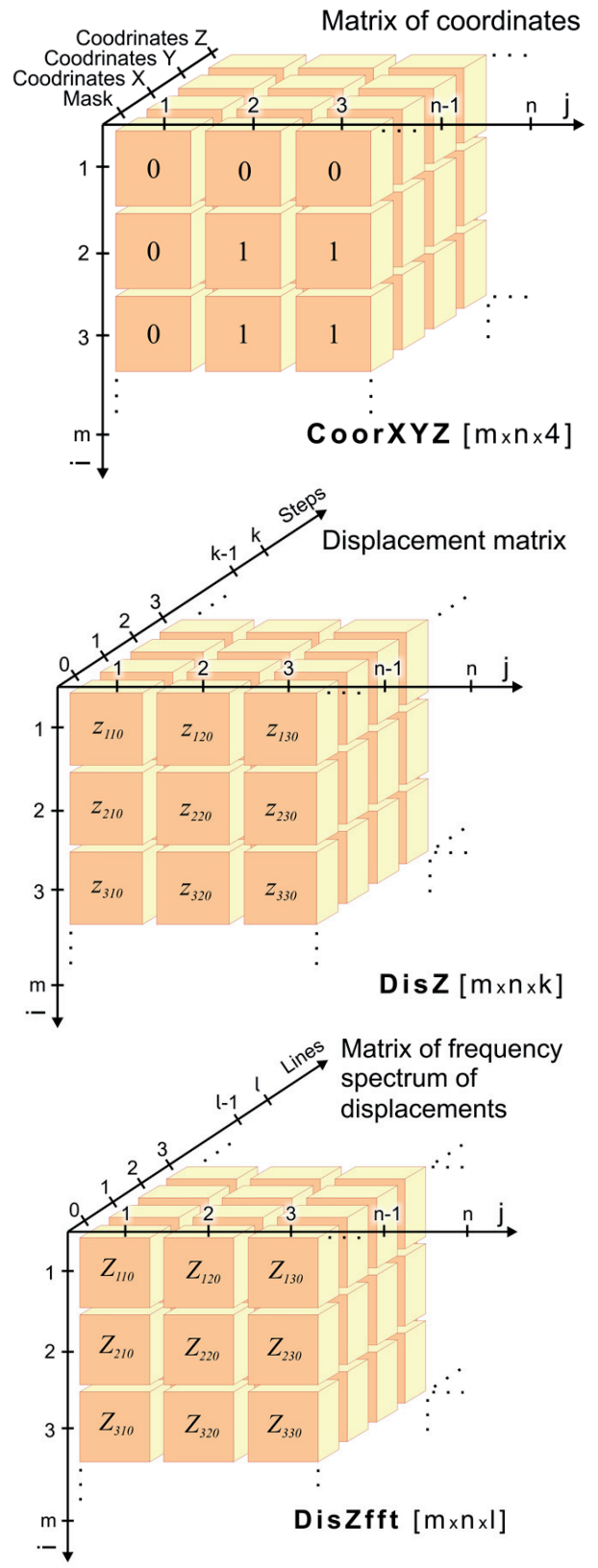

Frequency sequence

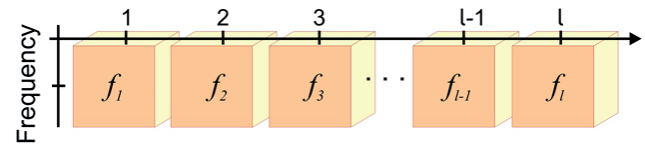

Fig. 4: Coordinate matrix CoorXYZ, matrix of displacements DisZ of grid points, matrix of average frequency spectrum of displacements DisZfft and frequency sequence.

From all time steps, there are read displacements of points and consequently is created the threedimensional matrix of displacements Disz with elements $z_{i j k}$ that represents displacement of given point in certain step i.e. in time. The indices $i$ and $j$ define point of a grid, index $k$ the time step (Fig. 4).

The frequency-dependent displacements are obtained by Fast Fourier Transformation of their time behaviour. The matrix of displacement frequency spectrum DisZfft (Fig. 4) is then created by elements $Z_{i j l}$ where index $l$ represents value of corresponding frequency in frequency sequence $\boldsymbol{f}$ (Fig. 4).

The average displacement of surface for every frequency is computed by averaging values of all points, which gives as frequency dependence of average displacements $\bar{Z}=\bar{Z}(f)$.

In Fig. 5 is shown example of average frequency spectrum of displacements generated by program Modan. The user then can choose a frequency the eigenshape of which he wants plot.

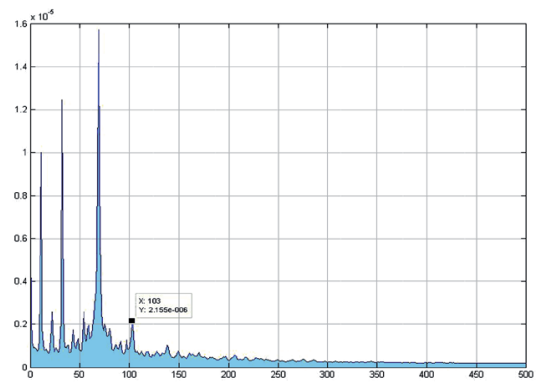

Fig. 5: Example of average frequency spectrum of displacements of ventilator blade.

From the matrix of displacement frequency spectrum Diszfft the algorithm read values of displacements of all points of the grid $Z_{i j l}$ for chosen frequency $f_{l}$. These values are multiplied by appropriate magnification coefficient, they are assigned to reference coordinates of grid and smoothing functions smooth the resulting new matrix of co- 
ordinates of grid point. This process transforms the reference grid of surface to the form that corresponds to eigenshape of object for given frequency and this shape is depicted in colors as can be seen in Fig. 6.

In Fig. 7 is shown graphical user interface of Modan program. The main window is divided into nine parts. The part (1) is control panel with ten buttons. The part (2) serves to choose a direction of vibration. Average frequency spectrum of displacement in chosen direction is displayed in the windows (3) and (4).

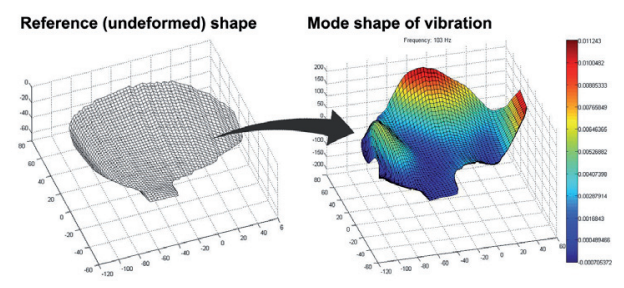

Fig. 6: Visualization of eigenshape of ventilator blade.

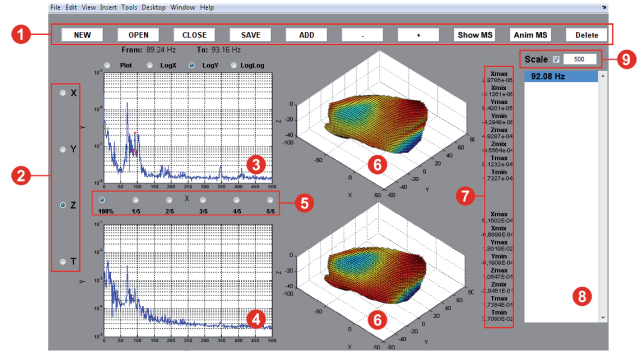

Fig. 7: Graphical user interface of Modan.

These windows also serve to finding peak frequencies. A chart displayed in the window (4) represents average frequency response without rigid body movements. An approaching one of the five intervals of frequency range is realized by clicking on radio buttons of the part (5). Modal shapes of vibration are shown in the windows (6). The part (7) shows maximal and minimal values of displacements. The field (8) is list of selected eigenfrequencies. A scale of magnification can be changed by the text field (9).

\section{Experimental determination of mode shapes by DIC method}

The object of measurement was an interior part of automobile front door. The door was freely suspended using a rope. Investigated area can be char- acterized as relative flat surface with moderately complicated contour.

On the observed surface was sprayed, for purposes of correlation, black and white speckle pattern (Fig. 8). The object was excited by impact hammer Bruel \& Kjaer 8206 with plastic tip. Frame rate of cameras was $1000 \mathrm{fps}$ and total time of acquisition was 1 second. The measurement was done by two CCD cameras Phantom SpeedSense 9060 (Fig. 9) with image resolution of $1280 \times 800$ pixels. Coordinates of surface points and their spatial displacements were evaluated in every step of measurement in Q-450 software Istra 4D. The exported files with results were then processed in Modan.

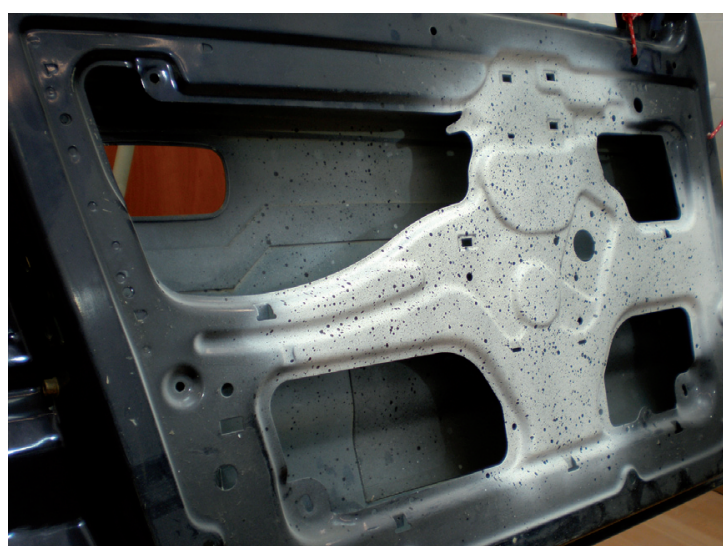

Fig. 8: Investigated area of the door.

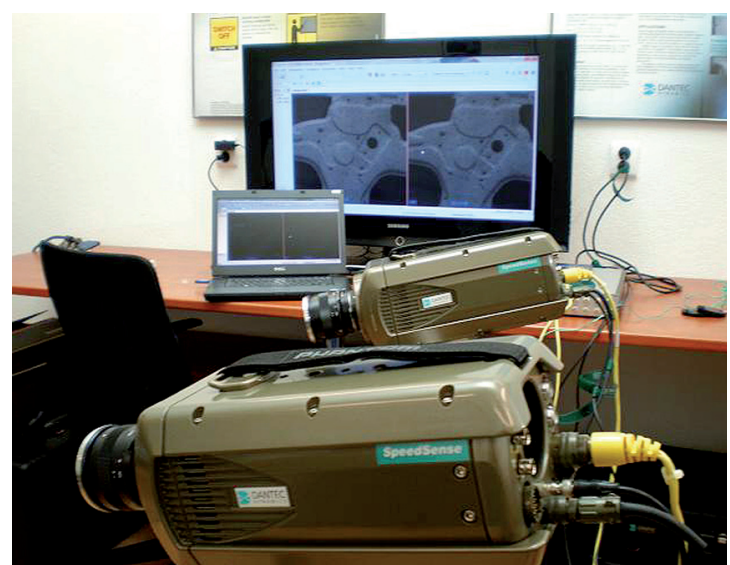

Fig. 9: System Q-450 with cameras Phantom SpeedSense 9060.

An evaluated contour of the investigated area can be seen in the Fig. 10. An evaluated contour of the investigated area can be seen in the Fig. 10.

In Fig. 11 is given graphical chart of frequency-dependence of averaged displacements of the object in direction $z$. 



Fig. 10: Contour of the investigated area.

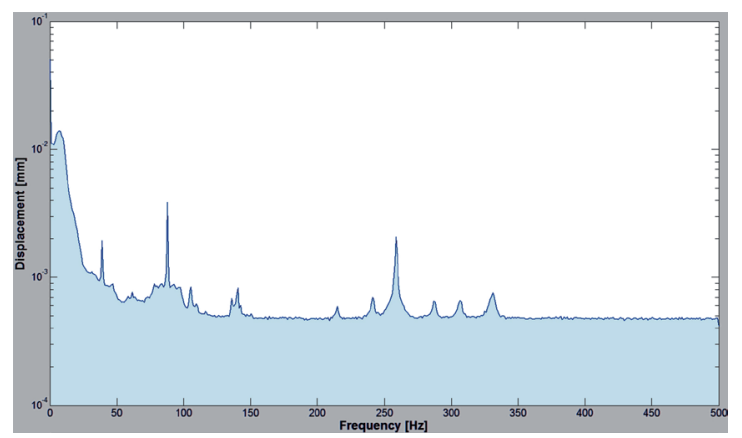

Fig. 11: Average frequency spectrum of displacement in Z direction carried out by MODAN.

On the basis of visualization of vibration shapes that correspond to frequencies where the average displacements have their local maxima, it was possible to identify individual modes of the door. Eigenfrequencies that were determined by this way in Modan are shown in the Table 1.

Table 1: Eigenfrequencies of the object.

\begin{tabular}{|l|l|l|l|l|l|}
\hline Mode & $\mathbf{1 .}$ & $\mathbf{2 .}$ & $\mathbf{3 .}$ & $\mathbf{4 .}$ & $\mathbf{5 .}$ \\
\hline Frequency $[\mathrm{Hz}]$ & 39.06 & 87.89 & 105.5 & 140.6 & 214.8 \\
\hline Mode & $\mathbf{6 .}$ & $\mathbf{7 .}$ & $\mathbf{8 .}$ & $\mathbf{9 .}$ & $\mathbf{1 0 .}$ \\
\hline Frequency $[\mathrm{Hz}]$ & 242.2 & 259.8 & 287.1 & 306.6 & 332.0 \\
\hline
\end{tabular}

Some interesting mode shapes of the door obtained by MODAN 1.0 are visualized in the Fig. 12, 13, 14 and 15. The deformation scaling factor was set to 1000:1 and a rigid body motion was removed.

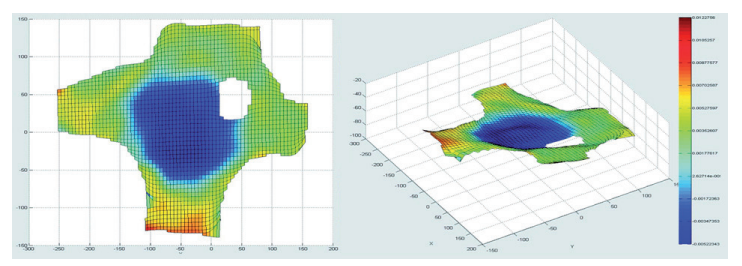

Fig. 12: Eigenfrequency $39.06 \mathrm{~Hz}-Z$ component of mode shapef.

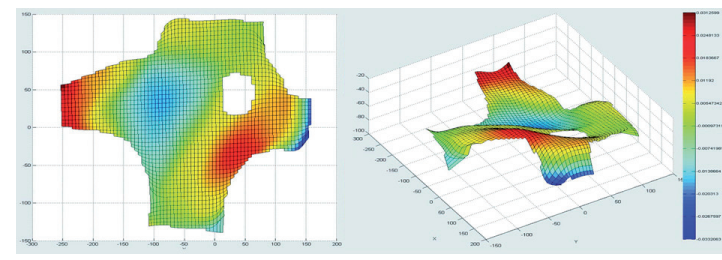

Fig. 13: Eigenfrequency $87.89 \mathrm{~Hz}-Z$ component of mode shape.

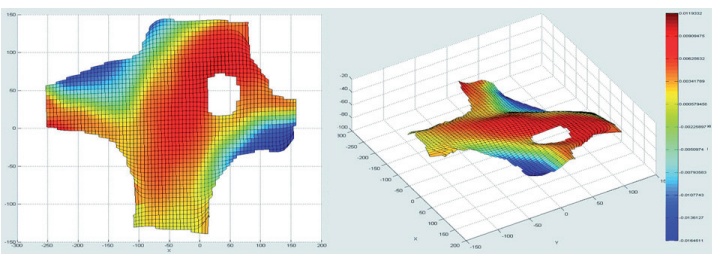

Fig. 14: Eigenfrequency $259.8 \mathrm{~Hz}-Z$ component of mode shape.

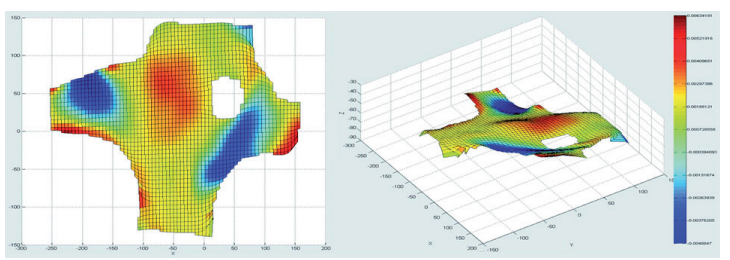

Fig. 15: Eigenfrequency $332.0 \mathrm{~Hz}-\mathrm{Z}$ component of mode shape.

\section{Conclusion}

The paper deals with problems of measurement of eigenshapes and eigenfrequencies by DIC method. The standard method of their measurement can be considered to be time-consuming and complicated and because of this there was proposed a new method that is restrained to only one measurement and accordingly saves time and costs for experiment. Its core lies on appropriate broadband excitation of object by impact hammer or by exciter with stochastic excitation signal, e.g. white noise. In the method is included software for processing of results from such a measurement. In the program Matlab was especially for system Q-450 developed software application Modan. This program is able to determine average frequency spectrum of displacements of surface points on object and then to determine individual eigenfrequencies. Modan represents separated eigenshapes graphically. Main advantage of using digital image correlation consists in spatial visualization of eigenshapes. Beside of resulting spatial shape, it is possible to represent also its components in directions $\mathrm{x}, \mathrm{y}$ and $\mathrm{z}$, respectively. 


\section{Acknowledge}

This contribution is the result of the project implementation: Center for research of control of technical, environmental and human risks for permanent development of production and products in mechanical engineering (ITMS:26220120060) supported by the Research \& Development Operational Programme funded by the ERDF. The authors would like to express their gratitude to Scientific Grant Agency VEGA MŠ SR for the support of this work under Proj ect No. 1/0289/11.

\section{References}

[1] TREBUŇA, F. - ŠIMČÁK, F. 2007. Príručka experimentálnej mechaniky, TypoPress, Košice, ISBN 970-80-8073-816-7

[2] BECKER T., SPLITTHOF K., SIEBERT T., KLETTING P.: Error Estimations of 3D Digital Image Correlation Measurements, Dantec Dynamics, Technical note, Germany, 2006

[3] TREBUŇA, F. - HUŇADY, R. - ZNAMENÁKOVÁ, M.: Using of Digital Image Correlation Method for Experimental Determination of Modal Parameters. In: Experimentální analýza napětí 2010, 48th International scientific conference: Velké Losiny, Czech Republic, May 31 - June 3, 2010, ISBN 978-80244-2533-7, str. $451-458$.

[4] TREBUŇA, F. - HUŇADY, R.: Využitie digitálnej obrazovej korelácie na určovanie vlastných tvarov a frekvencií sústavy. In: Jemná mechanika a optika. Vol. 55, no. 10 (2010), p. 276-279. - ISSN 0447-6441

[5] MILÁČEK, S. 1992. Modální analýza mechanických kmitů, České vysoké učení technické v Praze, ISBN 80-01-00872-X

[6] HUŇADY, R.: Možnosti využitia metódy digitálnej obrazovej korelácie v aplikáciách dynamiky. Dizertačná práca. Košice: Technická univerzita v Košiciach, Strojnícka fakulta, 2010.

[7] THE HDF GROUP [online]. Dostupné na internete: http:// www.hdfgroup.org/HDF5/

[8] DANTEC DYNAMICS GmbH. 2008. Istra4D / Software Manual Q-450 System

[9] Šimčák, F., Berinštet, V., Štamborská, M.: Some Possibilities of Determination of Yield Conditions for Cold Rolled Steel Sheets. In: Acta Mechanica Slovaca, vol. 14, no. 4, 2010, ISSN 1335-2393

[10] Élesztos, P., Écsi, L.: Parametrical Study of Free Vibration and Plastic Collapse of a Clamped Beam. In: Acta Mechanica Slovaca, vol. 14, no. 4, 2010, ISSN 1335-2393 